\title{
SISTEM PRODUKSI PADI ORGANIK DI KABUPATEN LAMPUNG TENGAH: ANALISIS USAHATANI DAN PASCAPANEN
}

(Production System of Organic Rice in Central Lampung Regency: Farming and Post-Harvest Analysis)

\author{
Revani Intan Putri ${ }^{1}$, Bustanul Arifin ${ }^{2}$ dan Sudarma Widjaya ${ }^{3}$
}

Jurusan Agribisnis, Fakultas Pertanian, Universitas Lampung, Jl. Prof. Dr. Soemantri Brojonegoro No. 1, Bandar Lampung, 35145,e-mail: bustanul.arifin@fp.unila.ac.id

\begin{abstract}
This research aims to know the farming income of organic rice; production risk and price risk faced by the organic rice farmers. This research was conducted in North Lampung Regency in March-April 2019. This sample of this research consists of 31 organic rice farmers which are taken by using census method. The data analysis method are farming income analysis and risk analysis which uses statistics method by counting variance, standard deviation, and coefficient of variation $(C V)$. The results showed that the average of farming income that was achieved by organic rice farmers amounted to IDR 60,525,621.96. The production and price risk are classified into the low category because the value of $\mathrm{CV}$ of production risk is 0.13 and $\mathrm{CV}$ of price risk is 0.10 .
\end{abstract}

Key words: income, organic rice, risk.

\section{PENDAHULUAN}

Pertanian konvensional dalam jangka panjang memberikan dampak buruk terhadap lingkungan pertanian. Bahkan, banyak penggunaan input usahatani pertanian konvensional yang tidak memperhatikan keseimbangan ekosistem (Saptana dan Ashari 2007). Menurut Sumarno (2007) Guna menyikapi hal tersebut, pemerintah mengarahkan pembangunan pertanian ke arah pertanian berkelanjutan. Pertanian berkelanjutan dicanangkan oleh pemerintah akibat dari dampak negatif intensifikasi pertanian dalam revolusi hijau.

Implementasi dari pertanian berkelanjutan adalah mulai diterapkannya sistem pertanian berbasis organik. Pada prinsipnya, pertanian organik sejalan dengan arah kebijakan Pembangunan Pertanian Nasional yaitu dalam upaya menuju pembangunan pertanian yang berkelanjutan (sustainable agriculture development). Keberlanjutan pertanian organik, tidak dapat dipisahkan dengan dimensi ekonomi, lingkungan dan sosial.

Pertanian organik tidak hanya sebatas meniadakan penggunaan input sintetis, tetapi bagaimana cara memanfaatkan sumber-sumber daya alam secara berkelanjutan, produksi makanan sehat dan menghemat energi. jika ditinjau dari aspek ekonomi dapat dikatakan berkelanjutan bila produksi pertaniannya mampu mencukupi kebutuhan dan memberikan pendapatan yang cukup bagi petani (Yanti 2005).

Provinsi Lampung terdiri atas tiga kabupaten yang menjadi sentra pengembangan usahatani padi organik, yaitu Kabupaten Pringsewu, Kabupaten Tanggamus, dan Kabupaten Lampung Tengah, namun usahatani tersebut masih dalam skala kecil. Petani yang membudidayakan padi organik di Kabupaten Lampung Tengah hanya 31 orang. Hal ini berarti terdapat beberapa hal yang menjadi permasalahan karena kecilnya skala pertanian berbasis organik khususnya budidaya padi organik.

Menurut Mimin, Musa dan Hari (2018), terdapat beberapa alasan yang mengindikasi minimnya petani padi organik di Kabupaten Lampung Tengah: (1) sistem budidaya padi organik dianggap rumit, salah satu kendala dari sulitnya persyaratan pemenuhan kriteria padi organik adalah letak sawah yang tidak berdampingan dengan aliran irigasi, dan tidak tercemar oleh bahan kimia; (2) hasil produksi padi organik masih rendah; (3) harga produk beras organik tinggi.

Masalah produksi berkenaan dengan sifat usahatani yang selalu tergantung pada alam didukung faktor risiko yang menyebabkan tingginya peluang-peluang untuk terjadinya kegagalan produksi, sehingga berakumulasi pada risiko rendahnya pendapatan yang diterima petani (Kurniati 2012). 
Penurunan produksi juga berkaitan dengan budidaya padi organik yaitu adanya risiko produksi. Masalah risiko diakibatkan oleh ketidakmampuan petani untuk memprediksi tentang apa yang akan terjadi pada waktu yang akan datang. Iklim dan kondisi alam yang tidak dapat diprediksi, mudah berubah, dan tidak dapat dikendalikan merupakan masalah yang harus dihadapi petani (Aprilliani 2016).

Selain risiko produksi petani sering kali dihadapkan dengan permasalahan harga yang berfluktuatif. Fluktuasi produktivitas tanaman padi akan mengakibatkan terjadinya fluktuasi harga baik di tingkat produsen maupun konsumen. Harga jual beras organik lebih tinggi sekitar $30-40 \%$ dibandingkan dengan padi anorganik. Berfluktuasinya harga beras ini akan berpengaruh juga pada permintaan beras organik di pasar walaupun penjualan hanya dalam skala kecil, selain itu besar kecilnya respon perbedaan harga ini tidak dipungkiri membuat permintaan beras organik masih rendah dikarenakan konsumen tertentu yang mengonsumsi beras organik.

Berdasarkan rumusan masalah tersebut, tujuan penelitian ini untuk: Mengetahui pendapatan usahatani padi organik dan mengetahui risiko produksi, risiko harga dalam usahatani padi organik di Kabupaten Lampung Tengah.

\section{METODE PENELITIAN}

Penelitian ini dilakukan dengan metode sensus yaitu suatu cara pengambilan sampel dengan menjadikan seluruh populasi sebagai responden penelitian dengan menggunakan kuisioner sebagai alat pengumpul data, sedangkan data sekunder diperoleh dari sumber yang memiliki keterkaitan dengan permasalahan penelitian seperti Badan Pusat Statistik, Dinas Pertanian Kabupaten Lampung Tengah, Balai Penyuluhan Pertanian, dan pustaka lainnya.

Penelitian dilakukan yaitu di Kabupaten Lampung Tengah yang terinci atas tiga kecamatan dengan jumlah sampel 31 responden. Kecamatan Trimurjo (Desa Untoro) sebanyak 9orang petani responden, Kecamatan Punggur (Desa Astomulyo) 14 orang petani responden, dan Kecamatan Seputih Raman (Desa Rejo Asri) 8 petani responden. Penelitian dilaksanakan pada bulan Maret sampai dengan April Tahun 2019.

Analisis pendapatan dihitung dengan menggunakan rumus menurut Soekartawi (2003):

$$
\pi=\mathrm{TR}-\mathrm{TC} \text { atau } \pi=\mathrm{Py} . \mathrm{Y}-(\mathrm{FC}+\mathrm{VC})
$$

$$
\begin{aligned}
& \text { Keterangan: } \\
& \Pi \quad=\text { Pendapatan }(\mathrm{Rp}) \\
& \mathrm{TR}=\text { Penerimaan }(\mathrm{Rp}) \\
& \mathrm{TC}=\text { Biaya total }(\mathrm{Rp}) \\
& \mathrm{Py}=\text { Harga produksi }(\mathrm{Rp} / \mathrm{kg}) \\
& \mathrm{Y}=\text { Jumlah produksi }(\mathrm{Kg}) \\
& \mathrm{FC}=\text { Biaya tetap }(\mathrm{Rp}) \\
& \mathrm{VC}
\end{aligned}
$$

Analisis pendapatan usahatani padi ini akan dilakukan pada satu musim tanam terakhir. Secara matematis dapat dihitung menggunakan rumus (Suratiyah 2015) yaitu :

$\mathrm{R} / \mathrm{C}=\mathrm{TR} / \mathrm{TC}$

Keterangan :

$\mathrm{R} / \mathrm{C}=$ Nisbah penerimaan total dengan biaya total

$\mathrm{TR}=$ Total penerimaan $(\mathrm{Rp})$

$\mathrm{TC}=$ Total biaya $(\mathrm{Rp})$

Jika :

Nilai R/C > 1, maka usahatani untung.

Nilai $\mathrm{R} / \mathrm{C}<1$, maka usahatani rugi.

Nilai $\mathrm{R} / \mathrm{C}=1$, maka usahatani berada pada titik impas/break event point.

Pendapatan usahatani merupakan selisih dari penerimaan usahatani dengan biaya total usahatani. Jika penerimaan usahatani lebih besar dari total biaya usahatani maka kegiatan usahatani mengalami keuntungan.

Menurut Kadarsan (1995) Analisis risiko produksi dapat diketahui dengan menghitung nilai yang diharapkan atau hasil rata-rata, ragam, simpangan baku koefisien varians, dan batas bawah. Ukuran untuk hasil yang diharapkan adalah hasil rata-rata atau mean, rumusnya yaitu:

$$
\mathrm{E}=\frac{\sum_{1=1}^{\mathrm{n}} \mathrm{E}_{\mathrm{i}}}{\mathrm{n}}
$$

Keterangan:

$\mathrm{E}$ = Nilai rata-rata hasil yang diharapkan (mean)

$\mathrm{Ei}=$ Hasil bersih per hektar pada tahun ke-1

$\mathrm{N}$ = Jumlah pengamatan

Ukuran rumus ragam adalah sebagai berikut:

$$
\mathrm{V}^{2}=\frac{\sum_{\mathrm{i}=1}^{\mathrm{n}}\left(\mathrm{E}_{\mathrm{i}}-\mathrm{E}\right)^{2}}{(\mathrm{n}-1)}
$$


Sedangkan Simpangan Baku merupakan akar dari ragam, atau secara matematis dapat ditulis sebagai berikut:

$$
\mathrm{V}=\frac{\sqrt{\sum_{\mathrm{i}=1}^{\mathrm{n}}(\mathrm{Ei}-\mathrm{E})^{2}}}{(\mathrm{n}-1)}
$$

Keterangan :

$\mathrm{V}^{2}=$ Ragam

$\mathrm{V}=$ Simpangan baku

$\mathrm{E}=$ Rata-rata hasil yang diharapkan

$\mathrm{Ei}=$ Hasil yang diharapkan pada periode ke-i

$\mathrm{N}=$ Jumlah periode pengamatan

Untuk memilih alternatif yang memberikan risiko paling sedikit dalam mengharapkan suatu hasil dapat dipakai keuntungan koefisien variasi yang rumusnya adalah :

$$
\mathrm{CV}=\frac{\mathrm{V}}{\mathrm{E}} \text {. }
$$

Keterangan:

$\mathrm{V}=$ Simpangan baku

$\mathrm{E}=$ Hasil rata-rata (mean)

Besarnya nilai koefisien variasi menunjukkan besarnya risiko yang dihadapi oleh petani. Nilai koefisien variasi usahatani kecil maka karakteristik usahatani memiliki risiko rendah. Sebaliknya jika nilai koefisien variasi usahatani besar maka karakteristik usahatani memiliki risiko besar.

Batas bawah (L) menunjukkan nilai terendah pendapatan yang mungkin diterima oleh petani. Rumus perhitungan batas bawah (L) adalah:

$\mathrm{L}=\mathrm{E}-2 \mathrm{~V}$

Keterangan:

$\mathrm{L}=$ Batas bawah

$\mathrm{E}=$ Rata-rata hasil yang diharapkan

$\mathrm{V}=$ Simpangan baku

\section{HASIL DAN PEMBAHASAN}

\section{Karakteristik Petani Responden}

Rata-rata umur petani padi organik di Kabupaten Lampung Tengah sebagian besar berada pada usia yang produktif, pada rentang usia 20-65 tahun. Petani padi organik pada tingkat pendidikan mayoritas tamat pada jenjang SLTA. Hal ini menunjukkan bahwa petani padi organik sudah mengenyam pendidikan pada tingkat pendidikan yang relatif baik. Pengalaman petani padi organik dalam berusahatani berkisar antara 1-20 tahun dengan jumlah petani mencapai 21 orang serta berpresentase sebesar $67,74 \%$. Lama pengalaman seseorang petani dalam menggeluti usahataninya maka kemampuan petani tersebut akan semakin baik. Jumlah petani yang memeiliki pekerjaan sampingan sebanyak 16 orang dengan persentase sebesar $51,61 \%$. Rata-rata pekerjaan sampingan yang dikerjakan petani padi organik yaitu buruh, berdagang dan kuli bangunan

\section{Luas lahan dan status kepemilikan lahan}

Luas lahan merupakan lahan total yang dimiliki petani dalam berbudidaya usahatani padi organik. Luas lahan merupakan salah satu indikator banyak produksi yang dihasilkan petani padi organik. sebagian besar petani padi organik di Kabupaten Lampung Tengah memiliki luas lahan berkisar antara 0,25-0,40 ha dengan persentase sebesar $70,97 \%$ berdasarkan survei turun lapang, luas lahan padi organik memang relatif kecil dibandingkan dengan padi konvensional.

Luas lahan yang dimiliki akan berpengaruh terhadap besar kecilnya produksi dan berpengaruh pula terhadap pendapatan petani. Selain itu, semakin luas lahan yang digarap oleh petani, maka semakin besar upaya petani untuk memanfaatkan sumber permodalan yang tersedia. Status kepemilikan lahan petani semuanya adalah milik sendiri yang diperoleh dari membeli dari perseorangan, perusahaan, warisan dan pemberian orang tua. Biaya sewa yang berlaku di Kabupaten Lampung Tengah adalah Rp 1.500.000 pertahun.

\section{Pola Tanam Usahatani Padi Organik}

Pada umumnya petani padi organik menanam padi organik pada lahan sawah tiga kali dalam setahun. Waktu penanaman padi organik di Kecamatan Seputih Raman dimulai pada bulan Februari. Pola tanam di Kecamatan Trimurjo di mulai bulan Januari sedangkan untuk di Kecamatan Punggur dimulai bulan Februari. Pola tanam padi organik di Kabupaten Lampung Tengah terdiri dari tiga musim tanam dalam satu kali musim tanam berlangsung selama kurang lebih 4 bulan.

\section{Budidaya padi organik}

Budidaya padi organik di Kabupaten Lampung Tengah dimulai pada tahun 2012. Sarana produksi yang digunakan petani padi organik di Kabupaten Lampung Tengah dalam berusahatani padi organik 
adalah benih, pupuk organik, pupuk kandang, pupuk cair meliputi cairan MOL (Mikroorganisme Local), pestisida nabati, dan penggunaan tenaga kerja.

Tahap kegiatan budidaya padi organik dimulai dari kegiatan persemaian, Persemaian merupakan cara yang terpenting dalam pemilihan kualitas benih terbaik. Benih yang biasa digunakan adalah benih dengan varietas mentik susu, pandang wangi, siantur, merah dan hitam. Tahap kedua yaitu pengolahan lahan. Dalam pengolahan lahan dilakukan dengan cara dibajak dan dicangkul. Biasanya dilakukan minimal dua kali pembajakan yakni pembajakan kasar dan pembajakan halus yang diikuti dengan pencangkulan kemudian lahan yang dibajak tadi harus segera dialiri oleh air selama satu hari. Setelah melakukan kegiatan pengolahan lahan selanjutnya dilakukan penanaman. Penanaman adalah proses pencaplakan (pembuatan jarak tanam), jarak tanam yang baik adalah jarak tanam sesuai dengan metode SRI yakni biasanya $25 \times 25 \mathrm{~cm}$ atau $30 \times 30 \mathrm{~cm}$.

Pupuk yang digunakan dalam padi organik ini terdapat dua jenis. Pertama, pupuk padat dan kedua pupuk cair. Pupuk padat ini merupakan pupuk yang dapat diaplikasikan lewat akar bisa berpupuk kandang dan pupuk kompos, sedangkan pupuk berbentuk cair berupa cairan MOL (Mikroorganisme Local) dan pestisida nabati dapat diaplikasikan lewat daun. Hama yang sering menyerang padi organik biasanya adalah hama putih, thrips, wereng, walang sangit, kepik hijau, penggerek batang padi, tikus, dan burung. Sementara itu penyakitnya adalah penyakit bercak daun coklat. Pengendalian hama dapat dilakukan dengan menyemprotkan pestisida nabati dan agen hayati (musuh alami) untuk mencegah semakin banyaknya hama yang muncul pada tanaman.

Padi mulai berbunga pada umur 2-3 bulan bulan dan bisa dipanen rata-rata pada umur sekitar 3,5 bulan atau sekitar 115 hari setelah tanam namun hal ini tetap tergantung jenis dan varietasnya. Misalnya varietas mentik susu panen dapat dilakukan pada umur kurang lebih 125 hari setelah tanam. Biasanya setelah dilakukan kegiatan panen lahan tersebut dapat dimanfaatkan untuk menanam tanaman kacang seperti kacang tanah, kacang hijau, kacang kedelai. Namun, setelah proses panen lahan sebaiknya diistirahatkan terlebih dahulu kurang lebih 30 hari. Perlakuan ini bertujuan agar mengembalikan tingkat kesuburan tanah kembali serta upaya untuk memutus siklus hama dan penyakit pada saat tanam sebelumn

Penjemuran untuk padi organik dijemur dengan terik yang tidak terlalu panas dan tidak terlalu dingin artinya jam untuk menjemur padi organik dengan media terpal biasanya pada pukul 08.0012.00 WIB dan dilanjutkan pada pukul 13.0015.00 WIB dan dibalik tiap 1 jam atau 2 jam sekali. Waktu lamanya penjemuran ini sejalan dengan penelitian Listyawati (2007), menyatakan bahwa pada saat proses pengeringan, sebaiknya gabah dibalik 2 jam sekali untuk mencegah kenaikan suhu. Proses penjemuran dilakukan agar pada saat digiling nantinya kualitas beras tersebut tidak menurun.

\section{Pengunaan Faktor Produksi Padi Organik}

Benih merupakan faktor penting dalam peningkatan produksi.Petani padi organik di Kabupaten Lampung Tengah semuanya menggunakan benih penangkaran lokal. Artinya benih tersebut merupakan benih hasil sendiri atau beberapa orang petani pada musim sebelumnya. Varietas benih padi organik yang digunakan antara lain; Mentik Susu, Pandan Wangi, dan Siantur serta beberapa petani ada yang menanam Beras Merah dan Hitam. Hasil penelitian menunjukkan bahwa penggunaan benih per-hektar di lahan padi organik sangat bervariasi mulai dari $5-28 \mathrm{Kg}$ perhektar. Pupuk yang digunakan dalam budidaya ini adalah pupuk organik. Petani biasanya memberikan pupuk sebanyak 1-2 kali dalam satu musim. Untuk mencegah dan memberantas hama penyakit serta gulma yang mengganggu tanaman. Petani padi organik memberikan pestisida nabati dengan rata-rata penggunaan sebanyak 12,88 Liter/ha.

Tenaga kerja yang digunakan oleh petani terdiri dari dua tenaga kerja yaitu tenaga kerja dalam keluarga (TKDK) dan tenaga kerja luar keluarga (TKLK). Tenaga kerja dihitung dengan menggunakan satuan hari kerja pria (HKP). Petani padi organik di Kabupaten Lampung Tengah lebih memilih melakukan kegiatan budidaya padi organik sendiri karena petani padi organik menganggap bercocok tanam padi ini memerlukan ketelitian dan kesabaran yang ekstra agar keberhasilan usahatani ini dapat berprospek lebih baik kedepannya. 


\section{Analisis Pendapatan Usahatani Padi Organik di Kabupaten Lampung Tengah.}

Pendapatan usahatani padi organik diperoleh dari selisih antara total penerimaan dengan total biaya usahatani padi organik. Penerimaan usahatani merupakan hasil perkalian antara harga jual dengan jumlah produksi. Biaya usahatani dibagi menjadi dua yaitu biaya tunai dan biaya diperhitungkan. Biaya tunai terdiri dari biaya penggunaan tenaga kerja luar keluarga, biaya penggunaan pupuk cair, pupuk kandang, pembayaran pajak lahan, pembelian karung padi serta biaya irigasi. Biaya diperhitungkan terdiri atas penggunaan benih turunan, penyusutan alat-alat pertanian, tenaga kerja dalam keluarga, pupuk kompos, penggunaan pestisida nabati dan biaya sewa lahan (milik).

Pendapatan perhektar usahatani padi petani organik atas biaya total sebesar Rp 60.525.621,96. Perbandingan penerimaan dengan biaya (rasio $\mathrm{R} / \mathrm{C}$ ) ini terdiri dari rasio $\mathrm{R} / \mathrm{C}$ total yang merupakan rasio antara penerimaan total rata-rata dengan biaya total rata-rata dan rasio $\mathrm{R} / \mathrm{C}$ tunai yang merupakan rasio antara penerimaan total dengan biaya tunai rata-rata. Nisbah penerimaan terhadap biaya total pada usahatani padi organik adalah sebesar 5,42 artinya setiap $\mathrm{Rp} \mathrm{1,00} \mathrm{biaya}$ total yang dikeluarkan akan menghasilkan penerimaan sebesar Rp 5,42.

Nisbah penerimaan terhadap biaya total yang lebih besar dari 1,00 menunjukkan bahwa usahatani padi organik di Kabupaten Lampung Tengah yang dilakukan oleh petani responden secara ekonomi menguntungkan. Perhitungan rata-rata biaya per ha yang digunakan dalam usahatani padi organik di Kabupaten Lampung Tengah.

Hasil R/C Ratio ini sejalan dengan penelitian Simamora (2014) yang melakukan penelitian berjudul "Analisis Pendapatan Usahatani Padi Organik" dengan studi kasus Kecamatan Beringin, Kabupaten Deli Serdang, Provinsi Sumatera Utara. Hasil analisisnya bahwa Nilai R/C yang diperoleh $5,54>1$ maka usahatani padi organik di daerah penelitian menguntungkan.

Tabel 1. Rata-rata pendapatan petani padi organik di Kabupaten Lampung Tengah

\begin{tabular}{|c|c|c|c|c|c|}
\hline No & Uraian & Satuan & Harga & Jumlah & Nilai \\
\hline \multirow[t]{2}{*}{1} & Penerimaan & $\overline{\mathrm{Rp}}$ & & & $75.248 .172,04$ \\
\hline & Produksi Beras & $\mathrm{Kg}$ & $16.000,00$ & $4.703,01$ & $75.248 .172,04$ \\
\hline \multirow[t]{16}{*}{2} & Biaya Produksi & & & & \\
\hline & Biaya Tunai & $\mathrm{Rp}$ & & & $5.843 .431,90$ \\
\hline & TK Luar Keluarga & HKP & $60.000,00$ & 47,13 & $2.827 .919,35$ \\
\hline & Pupuk Cair Perangsang & Liter & $50.000,00$ & 20,30 & $1.015 .161,29$ \\
\hline & Pupuk Kandang & $\mathrm{Kg}$ & 500,00 & $3.340,86$ & $1.670 .430,11$ \\
\hline & Pajak & $\mathrm{Rp}$ & & & $70.000,00$ \\
\hline & Karung Padi & $\mathrm{Rp}$ & & & $95.189,97$ \\
\hline & Biaya Irigasi & $\mathrm{Rp}$ & & & $164.731,18$ \\
\hline & Biaya Diperhitungkan & & & & $8.879 .118,18$ \\
\hline & Benih & $\mathrm{Kg}$ & $11.451,61$ & 17,60 & $191.806,45$ \\
\hline & Penyusutan Alat & $\mathrm{Rp}$ & & & $995.846,67$ \\
\hline & TK Dalam Keluarga & HKP & $60.000,00$ & 43,31 & $2.598 .561,83$ \\
\hline & Pupuk Kompos & $\mathrm{Kg}$ & 500,00 & $2.481,18$ & $1.240 .591,40$ \\
\hline & Pestisida Nabati & Liter & $41.935,48$ & 12,88 & $557.688,17$ \\
\hline & Sewa Lahan (milik) & $\mathrm{Rp}$ & & & $3.294 .623,66$ \\
\hline & Biaya Total & $\mathrm{Rp}$ & & & $14.722 .550,08$ \\
\hline \multirow[t]{3}{*}{3} & Pendapatan & & & & \\
\hline & Atas Biaya Tunai & $\mathrm{Rp}$ & & & $69.404 .740,14$ \\
\hline & Atas Biaya Total & $\mathrm{Rp}$ & & & $60.525 .621,96$ \\
\hline \multirow[t]{3}{*}{4} & R/C Rasio & & & & \\
\hline & Atas Biaya Tunai & $\mathrm{Rp}$ & & & 13,32 \\
\hline & Atas Biaya Total & $\mathrm{Rp}$ & & & 5,42 \\
\hline
\end{tabular}




\section{Analisis Risiko Usahatani Padi Organik di Kabupaten Lampung Tengah.}

Pada penelitian ini, jumlah produksi menggunakan data selama 5 musim tanam terakhir (MT-4, MT-3, MT-2, MT-1, dan MT). Pada Gambar 1, produksi terendah terjadi pada MT-1. Hal ini dapat terjadi karena pada musim tanam pertama merupakan proses peralihan dari lahan konvensional menjadi lahan organik yang membutuhkan waktu dan penyesuaian. Lahan yang mulanya konvensional harus diperbaiki terlebih dahulu struktur tanahnya oleh sebab itu pada musim tanam pertama hasil produksi padi organik belum maksimal.

Produksi tertinggi terjadi pada musim tanam MT terakhir mencapai $4.703,01 \mathrm{~kg} / \mathrm{ha}$, pada tahap ini petani sudah mulai mengerti cara budidaya yang baik dan struktur tanahnya juga sudah mengandung banyak akan bahan organik. Untuk mengetahui alternatif yang memberikan risiko paling sedikit dalam mengharapkan suatu hasil dapat dipakai koefisien variasi. Nilai koefisien variasi usahatani kecil maka karakteristik usahatani memiliki risiko rendah. Sebaliknya jika nilai koefisien variasi usahatani besar maka karakteristik usahatani memiliki risiko besar.

Menurut Muzdalifah (2010) risiko produksi yang dihadapi petani padi organik dipengaruhi oleh luas lahan, jumlah benih, jumlah pupuk, jumlah tenaga kerja, dan varietas benih. Faktor-faktor yang berpengaruh positif terhadap peningkatan produksi yaitu luas lahan, jumlah benih, dan varietas benih. Peningkatan faktor-faktor tersebut juga akan meningkatkan banyak risiko produksi. Sebaliknya, peningkatan jumlah pupuk akan menurunkan risiko produksi.

Risiko produksi pada usahatani padi organik di Kabupaten Lampung Tengah selama 5 musim tanam. Pada hasil penelitian nilai rata-rata (Mean) $4.319,78 \mathrm{~kg} / \mathrm{ha}$ sedangkan besarnya risiko pada Standar Deviasi $(\sigma)$ sebesar 548,76 kg/ha.

Koefesian CV sebesar 0,13 , artinya petani padi organik dalam setiap musim tanam memiliki peluang kehilangan sebesar 0,13 . Risiko produksi petani padi organik tergolong rendah dan petani masih dapat menanggulangi risiko tersebut. Nilai batas bawah (L) produksi sebesar 3.222, $26 \mathrm{~kg}$ perhektar artinya, kemungkinan produksi terendah yang dapat menyebabkan risiko sebesar Rp 3.222, $26 \mathrm{~kg}$ perhektar.

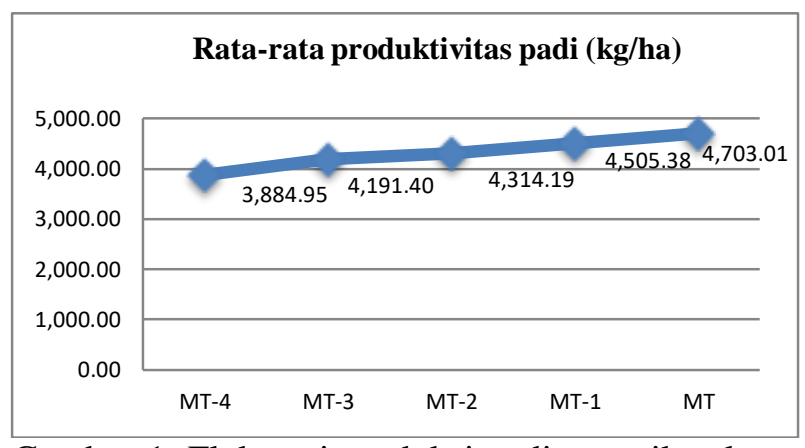

Gambar 1. Fluktuasi produksi padi organik selama lima musim tanam

Menurut Asbullah (2017) terdapat tindakan untuk mengurangi risiko produksi pada usahatani padi organik yaitu dengan melakukan perlindungan hama dan penyakit terhadap tanaman serta menerapkan input organik sesuai standar oprasional prosedur yang ditetapkan supaya produksi yang diperoleh dapat optimal. Misalnya, dengan menggunakan benih yang berkualitas. Benih yang berkualitas mampu beradaptasi, memiliki pertumbuhan yang cepat serta seragam, tumbuh lebih cepat, dan tinggi nilai produktivitasnya.

Pemilihan benih berkualitas dapat dilakukan dengan mudah, yaitu dengan merendam benih dalam larutan garam dengan menggunakan indikator telur. Letakkan telur di dasar air dan masukkan garam hingga telur terangkat di permukaan. Selanjutnya telur diambil dan masukkan benih padi. Benih yang mengambang dibuang. Terdapat berbagai macam cara penanaman padi, namun lebih disarankan dengan cara tanam jajar legowo $2: 1(40 \times(20 \times 10) \mathrm{cm}$. Cara tanam ini akan memberikan jumlah populasi yang banyak dengan produksi lebih tinggi dibanding dengan cara konvensional. Selain itu kelebihan cara tanam ini adalah memudahkan perawatan. Rendahnya risiko produksi usahatani organik antara lain dikarenakan kesuburan tanah yang terpelihara dan keseimbangan ekosistem yang mampu menekan gangguan hama dan penyakit tanaman.

Tabel 2. Rata-rata risiko produksi usahatani padi organik di Kabupaten Lampung Tengah

\begin{tabular}{lr}
\hline Keterangan & Per hektar \\
\hline Mean $(\mathrm{E})$ & $4.319,78$ \\
Simpangan Baku (V) & 548,76 \\
Koefesien Variasi (CV) & 0,13 \\
Batas Bawah (L) & $3.222,26$ \\
\hline
\end{tabular}


Iklim yang tidak menentu menyebabkan risiko produksi meningkat pada padi karena curah hujan yang terlalu tinggi dan terlalu rendah menyebabkan timbulnya berbagai macam hama dan penyakit yang menyerang pertanaman padi.

\section{Risiko Harga}

Sebagaimana komoditas pertanian pada umumnya, padi juga sering mengalami fluktuasi harga.Harga beras organik yang terendah diterima petani responden selama lima musim tanam terakhir terjadi pada MT 1 dan MT 2 tahun 2017 yaitu sebesar $\mathrm{Rp} 13.000,00$ per $\mathrm{kg}$, hal ini terjadi karena pada awal pengenalan beras organik petani padi organik masih mencoba membuat konsumen mengerti tentang manfaat dari beras organik yang bebas akan pestisida kimia. Besar kecil perbedaan harga beras organik dengan konvensional membuat konsumen pun mempertimbangkan ulang untuk membeli beras organik dengan harga tinggi ini. Harga beras organik tertinggi terjadi pada MT 4 dan MT 5 sebesar Rp 16.000,00 per kg.

Pada MT-3 (musim tanam keempat) dan MT-4 (musim tanam kelima) harga beras organik dengan fluktuasi harga paling tinggi, dikarenakan pada musim tanam keempat dan kelima ini petani sudah ada sertifikat resmi INOFICE (Indonesian Organic Farming Certification) sertifikat ini merupakan jaminan mutu resmi dari pemerintah terhadap produk berbasis organik. Jadi pada saat musim tanam tersebut, petani berani menjual beras organik tersebut dengan harga tinggi selain itu, hal yang mendasari petani berani menjual dengan harga dua kali lebih besar dari beras konvensional adalah, dewasa ini telah terjadi pergeseran selera konsumen, dari yang mengutamakan kuantitas sekarang telah beralih kepada kualitas. Masyarakat telah sadar akan pentingnya kesehatan yang dapat bersumber dari makanan. Salah satu sumber bahan makanan yang tidak mengandung zat kimia atau berbahaya adalah beras organik.

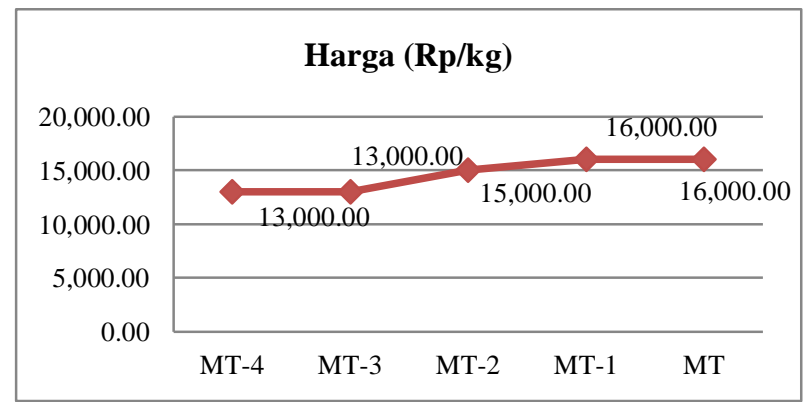

Gambar 2. Fluktuasi harga beras organik selama lima musim tanam
Tabel 3. Rata-rata risiko harga beras organik di Kabupaten Lampung Tengah

\begin{tabular}{lr}
\hline Keterangan & Per hektar \\
\hline Mean $(E)$ & $14.600,00$ \\
Simpangan Baku (V) & $2.300 .00,00$ \\
Koefesien Variasi $(C V)$ & 0,10 \\
Batas Bawah (L) & $11.566,85$ \\
\hline
\end{tabular}

Harga beras organik yang relatif mahal ini disebabkan oleh besarnya manfaat beras organik bagi kesehatan yaitu bebas dari kandungan bahan kimia berbahaya dan relatif tingginya faktor risiko dalam produksi (usahatani) yang dihadapi oleh petani akibat tidak menggunakan pestisida dan pupuk anorganik (Soetrisno 1999).

Menurut penelitian Naftaliasari, Abidin dan Kalsum (2015) menyebutkan bahwa harga produk merupakan salah salah satu faktor yang memepertimbangkan petani dalam memutuskan untuk menanam suatu komoditas tertentu. Jika harga panen periode tanam sebelumnya relatif tinggi atau paling tidak memberikan tingkat keuntungan yang tinggi maka petani akan meningkatkan skala usahanya dengan melakukan berbagai cara seperti menyewa lahan dan meningkatkan luas areal tanam. Namun, tidak semua petani dapat melalukan hal tersebut, karena berbagai keterbatasan modal dan keterbatasan tenaga kerja keluarga.

Risiko harga merupakan risiko yang timbul sebagai akibat ketidakpastian dalam perubahan harga suatu produk. Dalam tiga tahun terakhir nilaikoefisien variasi $(\mathrm{CV})$ pada risiko harga sebesar 0,10 . Hal ini berarti petani padi organik memiliki risiko harga yang tergolong rendah.

\section{KESIMPULAN}

Berdasarkan hasil penelitian dapat disimpulkan bahwa pendapatan petani padi organik atas biaya total di Kabupaten Lampung Tengah sebesar Rp 60.525.621,96 perhektar dengan $\mathrm{R} / \mathrm{C}$ atas biaya total sebesar 5,42. Risiko produksi padi organik termasuk dalam kategori rendah dengan nilai $\mathrm{CV}$ sebesar 0,13 dan risiko harga petani padi organik juga memiliki risiko yang rendah dengan $\mathrm{CV}$ sebesar 0,10 .

\section{DAFTAR PUSTAKA}

Aprilliani R. 2016. Analisis Pendapatan dan Risiko Usahatani Padi Organik dan Anorganik di Kabupaten Pringsewu. Skripsi. Jurusan 
Agribisnis, Fakultas Pertanian, Universitas Lampung. Bandar Lampung.

Asbullah M, Hapsari TD, dan Sudarko. 2017. Analisis risiko pendapatan pada usahatani padi organik di Desa Lombok Kulon Kecamatan Wonosari Kabupaten Bondowoso. Jurnal Universitas Jember, 10(2).https://jurnal.unej.ac.id/index.php/JSEP/ issue/view/656 [15 Januari 2019]

Kadarsan HW. 1995. Keuangan Pertanian dan Pembiayaan Perusahaan Agribisnis. Gramedia Pustaka Utama. Jakarta.

Kurniati D. 2012. Analisis risiko produksi dan faktor-faktor yang mempengaruhinya pada usahatani jagung di Kecamatan Mempawah Hulu Kabupaten Landak. Jurnal Sosial Ekonomi Pertanian, 1 (3). http://jurnal.untan.ac.id/index.php/jsea/article/ viewFile/4366/4425 [5 Juni 2019].

Mimin A, Musa HW, dan Hari W. 2018. Hambatan Partisipasi petani Dalam pengembangan padi organik di Kabupaten Tasikmalaya (obstacles of farmers participation in organic rice development in tasikmalaya district). Institut Pertanian Bogor. Jurnal Pengelolaan Sumberdaya Alam dan Lingkungan. 8(3):330-338.

https://journal.ipb.ac.id/index.php/jpsl/article/ view/17342 [5 Desember 2018].

Muzdalifah. 2012. Analisis pendapatan dan risiko pendapatan usahatani padi daerah irigasi dan non irigasi di Kabupaten Banjar Kalimantan Selatan. Jurnal Jurusan Sosial Ekonomi Pertanian Fakultas Pertanian Universitas Lambung Mangkurat 1(1), April 2012, hlm 65-74. http:// jurnal.untan.ac.id [9 Oktober 2018].
Naftaliasari T, Abidin Z, Kalsum U. 2015. Analisis risiko usahatani kedelai Di Kecamatan Raman Utara Kabupaten Lampung Timur. Jurnal Sosial Ekonomi Pertanian, 3(2). http://jurnal.fp.unila.ac.id/index.php/JIA/articl e/view/1033/938 [6 Maret 2019].

Saptana dan Ashari, 2007. Pembangunan pertanian berkelanjutan melalui kemitraan usaha. Jurnal Litbang Pertanian 26 (4): 123-124 http://203.190.37.42/publikasi/p3264071.pdf[ 6 Maret 2019].

Simamora SMT. 2014. Analisis Pendapatan Usahatani Padi Organik (Studi Kasus Kecamatan Beringin, Kabupaten Deli Serdang, Provinsi Sumatera Utara). Skripsi. Program Studi Agribisnis, Fakultas Pertanian, Universitas Sumatera Utara. Medan.

Sumarno. 2007. Teknologi revolusi hijau lestari untuk ketahanan pangan nasional di masa depan. Jurnal Iptek Tanaman Pangan 2 (2): 132.http://ejurnal.litbang.pertanian.go.id/indx. php/ippan/article/view/2654 [16 Juni 2019].

Suratiyah, K. 2015. Ilmu Usahatani Edisi Revisi. Penebar Swadaya. Jakarta.

Soekartawi. 2003. Teori Ekonomi Produksi dengan Pokok Bahasan Analisis Cobb-Douglas. Raja Grafindo Persada. Jakarta.

Soetrisno Loekman. 1999. Pertanian pada Abad 21. Dirjen Perguruan Tinggi, Departemen Pendidikan dan Kebudayaan, Jakarta.

Yanti R. 2005. Aplikasi Teknologi Pertanian Organik: Penerapan Pertanian Organik oleh Petani Padi Sawah Desa Sukorejo Kabupaten Sragen. Skripsi. Http//:www.lib.ui.ac.id/ [18 Desember 2018].

Yulianti CP. 2019. Alokasi Faktor Produksi dan Sistem Pemasaran Padi Organik di Kabupaten Lampung Tengah. Skripsi. Universitas Lampung. Lampung. 